\title{
Extraction of Natural Dyes from Glycyrrhiza glabra and Lagerstroemia speciosa for Wool Dyeing and Testing of its Functional Properties
}

\author{
Aaditaa Singh* and Shahnaz Jahan
}

Department of Clothing and Textiles, College of Home Science, G.B. Pant University of Agriculture and Technology, Pantnagar, U.S. Nagar, Uttarakhand, 263145, India

*Corresponding author

\section{A B S T R A C T}

\section{Keywords}

Value addition,

Natural Dyes,

Antibacterial,

Glycyrrhiza glabra,

Lagerstoermia

speciosa

Article Info

Accepted:

15 November 2019

Available Online:

10 December 2019
In order to sustain the natural dyes, there is increased need to identify sources of natural dyes having high yield, good colour fastness and multifunctional properties. In this study, the dyeing potential of natural dyes extracted from locally available plants namely Glycyrrhiza glabra and Lagerstoermia speciosa will be evaluated on the basis of their antimicrobial activity and ultraviolet protection factor. The solutions of both the natural dyes were subjected to antibacterial testing against common human pathogens $S$. aureus and $E$. coli. These dyes were applied on wool fabric using standard conditions. The antibacterial activity, colour strength $(\mathrm{k} / \mathrm{s}), \mathrm{UPF}$ and fastness properties of both the dyed samples were assessed. The characterization of dye was done on the basis of FTIR and phytochemical analysis. The results demonstrate that both the natural dyes possess good antimicrobial activity against human pathogens and exhibits good UPF, colour fastness properties as well as colour strength. This study envisages the development of sustainable dyeing technique for wool fabric and also a potential alternative for providing antimicrobial finishing to the fabric.

\section{Introduction}

Value addition of textile material by using natural dyes is gaining popularity all over the world. Natural dyes are not an innovation but a revival of rich and prudent tradition and were used in the past until the discovery of synthetic dyes in the middle of $19^{\text {th }}$ century.
Most of the natural dyes have inherent antimicrobial properties and could consequently possess high medicinal activity. The antimicrobial activity of some of these dyes is due to the presence of phenol, tannin and quinone in their extracts. When these dyes were applied to textiles, the antimicrobial properties of these plant dyes contribute to the 
longer life of the textile materials (Calis et al., 2009)

The main requirements for a basic commercial setup of natural dye stuff production and natural dyeing are agricultural demands and meeting the requirements of technical dye houses. Agricultural demands include low cost production and harvesting of plant material, easy preparation of raw material/ dye powder and easy storage of raw materials. The technical dye houses requirements are simple and rapid dyeing process, acceptable fastness properties, no use of mordants specifically metallic mordants, non toxic properties of dye and its biodegradability in wastewater treatment plant (Bechtold et al., 2003). The study undertaken deals with the sustainable extraction of natural dyes from two plant species namely Glycyrrhiza glabra and Lagerstoermia speciosa, its application on pure wool fabric and assessment of its functional properties. The findings of this study will be helpful to increase the functionality of textile material such as UPF and antimicrobial activity as well as give acceptable fastness properties. Such multipurpose wool materials can be utilized for making value added products and also reduces the cost of additional finishing treatments. The residual plant material left after dyeing process can be further used as manure, fertilizer or soil conditioner because no chemicals and no organic solvents were used in the study during the entire process including extraction of dyes and dyeing of wool fabric.

\section{Experimental}

\section{Materials and Methods}

\section{Plant materials}

The plant materials i.e. roots of Glycyrrhiza glabra commonly known as Mulethi or
Liquorice (Family: Fabaceae) and waste leaves of Lagerstoermia speciosa or pride of India (Family: Lythraceae) were collected from the nearby areas of Pantnagar, Uttarakhand.

The collected material was washed using distilled water, shade dried, broken into smaller chips and grinded to powder form. Aqueous extraction method was used for dye extraction to avoid use of harmful chemicals as they pollute the nearby water resources.

\section{Textile Materials}

Wool fabric purchased from Gandhi Ashram, Haldwani Uttarakhand was used for dyeing with natural dyes. The fabric was washed using $0.5 \mathrm{ml}$ of liquid detergent in $100 \mathrm{ml}$ of water.

The physical properties of fabric such as fabric weight (ASTM D3775), tensile strength and elongation (IS: 1969-1968) were also assessed which are mentioned in Table 1.

\section{Test inoculums for antibacterial testing}

Staphylococcus aureus and Escherichia coli were used as reference microorganisms for testing antibacterial activity of the dyed and undyed samples. These strains have been used for study, as they are human pathogens and representative of gram positive and gram negative bacteria class.

\section{Chemicals used}

In this study, no chemicals were used for extraction of dyes. The chemicals were only used for phytochemical profiling of extracted dyes which are sulphuric acid $\left(\mathrm{H}_{2} \mathrm{SO}_{4}\right)$, ferric chloride $\left(\mathrm{FeCl}_{3}\right)$, sodium hydroxide $(\mathrm{NaOH})$, ether $\left(\mathrm{C}_{2} \mathrm{H}_{5}\right)_{2} \mathrm{O}$, hydrochloric acid (HCL), glacial acetic acid $\left(\mathrm{CH}_{3} \mathrm{COOH}\right)$ and zinc dust (Zn). 


\section{Extraction of natural dyes}

The dye solutions were prepared by extracting $2 \mathrm{~g}$ of each dyestuff in $100 \mathrm{ml}$ of distilled water at $80{ }^{\circ} \mathrm{C}$ for 60 minutes and the solutions were filtered using nylon mesh.

\section{Determination of $\lambda$-max}

The $\lambda$-max of the dye solutions were determined using "PC Based Double Beam UV-VIS spectrophotometer. The dye solutions were diluted upto 50 times to record the $\lambda$ $\max$.

\section{Assessment of antibacterial activity}

The extracted solutions were subjected for antibacterial testing against gram positive S.aureus and gram negative E.coli bacterias using disc diffusion method (AATCC-30).

The test bacterias were grown overnight in 10 $\mathrm{ml}$ nutrient broth i.e. potato dextrose agar and incubated at $37^{\circ} \mathrm{C}$. The test bacteria S.aureus and $E$. coli were streaked on sterile nutrient agar plates. Each dye solution $(10 \mathrm{ml})$ was impregnated onto a small disc of filter paper with diameter $5.0 \mathrm{~mm}$ and placed on top of prepared agar plates. The plates were incubated overnight at $37^{\circ} \mathrm{C}$ and zone of inhibition was measured.

\section{Characterization of natural dyes}

The colouring components present in dyes were identified on the basis of spectroscopic and chemical investigations. The FTIR analysis of both the dyes was done using bruker alpha model spectrophotometer to identify the different kind of materials, molecular composition and structure present in the selected dyes. Phytochemical analysis of both the dyes was also done using standard protocols given by CSWRI, Avikanagar as mentioned below:

\section{Tannins}

Five $\mathrm{ml}$ of dye extract was placed in a test tube and $2 \mathrm{ml}$ of ferric chloride (5\%) solution was added. Formation of greenish-black precipitate indicates the presence of tannins.

\section{Anthraquinones}

The dye extract was further extracted using ether and filtered. The extract was subjected to caustic soda. Formation of violet colour indicates the presence of anthraquinones.

\section{Anthocyanins and flavanones}

$1 \mathrm{ml}$ of dye extract was mixed with few drops of sodium hydroxide (10\%) followed by addition of sulphuric acid. Formation of blue colour followed by yellowish orange colour after addition of acid indicates the presence of anthocyanins. Formation of yellow to orange colour and crimson red after an addition of acid indicates the presence of flavanones.

\section{Coumarins}

Dye extract $(1 \mathrm{ml})$ was mixed with sodium hydroxide (10\%). The solution turns yellow in colour which indicates the presence of coumarins.

\section{Quinones}

One $\mathrm{ml}$ of dye extract was mixed with $1 \mathrm{ml}$ of concentrated sulphuric acid. Sodium hydroxide was also added for confirmation of the test. Red colour formation indicates the presence of quinones. Blue/green colour after addition of alkali confirms the presence of quinones.

\section{Glycosides}

In $0.2 \mathrm{ml}$ dye extract, $0.1 \mathrm{ml}$ of glacial acetic acid and few drops of 5\% ferric chloride 
solution was added. In this mixture, few $\mathrm{ml}$ of sulphuric acid was added. The formation of brown ring at interface having greenish blue colour solution indicates the presence of glycoside.

\section{Flavonoid}

Dye extract $(2 \mathrm{ml})$ was mixed with $2 \mathrm{ml}$ zinc dust and HCL was added gradually dropwise. The red colour of the solution indicates the presence of flavonoids in dye.

\section{Phenol}

Two $\mathrm{ml}$ of dye extract was mixed in $2 \mathrm{ml}$ of $2 \%$ ferric chloride. Formation of blue green colour indicates the presence of phenol.

\section{Saponin}

Two $\mathrm{ml}$ of dye extract was shaken vigorously in a test tube. Stable foam formation indicates the presence of saponnin.

\section{Terpenoids}

Dye extract $(2 \mathrm{ml})$ was mixed with $2 \mathrm{ml}$ chloroform and sulphuric acid. The formation of reddish brown colour at the interface indicates the presence of terpenoids in dye.

\section{Natural dyeing of wool fabric with extracted natural dyes}

Presoaked samples of wool fabric (2 g) were dyed using the prepared dye solutions at $80^{\circ} \mathrm{C}$ for 60 minutes. The samples were then cooled, rinsed, washed with water and dried in shade.

\section{Testing of functional properties of prepared fabric}

The wool fabrics dyed separately with mulethi and pride of India were further evaluated for its antibacterial activity (AATCC-147), colour strength $(\mathrm{k} / \mathrm{s})$, ultraviolet protection factor (UPF) using AATCC-183 method and colour fastness properties.

\section{Evaluation of antibacterial activity (AATCC-147)}

The test specimens of size $2.5 \times 5 \mathrm{~cm}$ were cut and $15-20 \mathrm{ml}$ of nutrient agar medium was poured in respective petri dishes, cool and left to set. The $10 \mathrm{ml}$ nutrient broth containing test organisms was kept overnight in incubator at $37^{\circ} \mathrm{C}$ and $120 \mathrm{rpm}$. The $4 \mathrm{~mm}$ inoculating loop full of test inoculums was loaded and streaked aseptically to the surface of prepared agar plates. The specimens were gently placed over the agar plates using sterilized forceps. Incubation of plates were done for 24 hours at $37^{\circ} \mathrm{C}$.

After 24 hours of incubation the plates were examined for growth interruption along the streaks of inoculums and beneath the specimen. The clear zone of inhibition beyond the edges of specimen was determined. The average width of inhibition zone for test specimen was calculated beyond the edges of specimens was determined using following formula:

$\mathrm{W}=\mathrm{T}-\mathrm{D} / 2$ Eq. (A.1)

Where, $\mathrm{W}=$ width of clear zone of inhibition in $\mathrm{mm}$.

$\mathrm{T}=$ total diameter of fabric specimen and clear zone in $\mathrm{mm}$

$\mathrm{D}=$ diameter of the fabric specimen in $\mathrm{mm}$

Measurement of colour strength and UPF of dyed samples

The colour strength of dyed fabric samples were measured using "Premier Colourscan SS5100A" spectrophotometer. The samples 
were folded twice and placed at the eye of the instrument and the light was projected onto it. The samples orientation was changed to five times and readings were recorded.

$\mathrm{k} / \mathrm{s}=\left[\left\{(1-\mathrm{R})^{2} / 2 \mathrm{R}\right\}\right] \mathbf{E q} \cdot(\mathbf{A . 2})$

Where $\mathrm{R}$ is the reflectance, $\mathrm{K}$ is absorbance and $\mathrm{S}$ is the scattering

Ultraviolet protection factor of dyed and undyed specimens were determined using AATCC-183:2004 test method at NITRA Ghaziabad. The instrument used for measuring UPF of samples was Compsec M 350 UVvisible spectrophotometer. The specimen of size $10 \times 10 \mathrm{~cm}$ was mounted on the port of instrument under standard atmospheric conditions. The UPF of the specimen was firstly taken in one direction, second measurement was taken at $45^{\circ}$ to the first orientation and third measurement was taken at $45^{\circ}$ to the direction of the second measurement. The average of three measurements of spectral transmittance was calculated.

The formula used for determining UPF of each specimen was:

$$
U P F=\frac{\Sigma E \lambda \times S \lambda \times \Delta \lambda}{\Sigma E \lambda \times S \lambda \times T \lambda \times \Delta \lambda} \ldots . . \mathrm{Eq} . \text { (A.3) }
$$

Where, $E_{\lambda}$ is relative erythemal spectral effectiveness, $S_{\lambda}$ is solar spectral irradiance, $T_{\lambda}$ is average spectral transmittance of the specimen (measured) and $\Delta_{\lambda}$ is measured wavelength interval $(\mathrm{nm})$

\section{Assessment of colour fastness}

The wool fabric dyed using mulethi and pride of India dyes were tested for various fastness properties such as washing fastness (IS: 6871979), rubbing fastness (IS: 766-1956) and light fastness (IS: 2454:1985).

\section{Results and Discussion}

\section{Wool fabric specifications}

The physical properties of wool fabric including fabric weight, tensile strength and elongation were assessed. The results are shown in Table 1.

\section{Determination of $\lambda$-max}

The $\lambda$-max of both the dyes were recorded by diluting the solution upto 50 times and was observed to be $390 \mathrm{~nm}$ in case of Glycyrrhiza glabra and $400 \mathrm{~nm}$ in case of Lagerstoermia speciosa dye.

\section{Assessment of antibacterial activity of extracted dyes}

The extracted dyes were subjected to test against antibacterial activity using disc diffusion method and results are shown in Table 2. The zone of inhibition was measured against both the bacteria i.e. S.aureus and E.coli.

It was found that Glycyrrhiza glabra showed excellent inhibition properties against S.aureus $(10 \mathrm{~mm})$ as compared to E.coli (6mm). Snafi, (2018) also reported that alcoholic extract of roots of Glycyrrhiza glabra showed strong antibacterial activity against S.aureus with an inhibition zone of $22 \mathrm{~mm}$ and E.coli with inhibition zone of 15 $\mathrm{mm}$.

The lowest zone of inhibition was obtained in case of Lagerstoermia speciosa against S.aureus $(3 \mathrm{~mm})$ whereas the dye possesses good antibacterial activity against E.coli (6mm). The findings of Diab et al., 2012 reported that methanolic extracts of Lagerstoermia leaves had bactericidal activity against S.aureus with inhibition zone of 30 $\mathrm{mm}$ and E.coli (26mm). 
Characterization of Glycyrrhiza glabra and Lagerstoermia speciosa dye

FTIR analysis of Glycyrrhiza glabra and Lagerstoermia speciosa dye

The spectral ranges obtained from FTIR have been used in identifying the components present in the dye extract. The FTIR peak values and functional groups of Glycyrrhiza glabra (GA) and Lagerstoermia speciosa (LS) are shown in Figure 1. The dye extract of Glycyrrhiza glabra (GA) showed characteristic absorption bands at $1063 \mathrm{~cm}^{-1}$, $1682 \mathrm{~cm}^{-1}$ and at $3310 \mathrm{~cm}^{-1}$. The peak at 1063 $\mathrm{cm}-1$ represents the presence of aliphatic amines (Theivandran et al., 2015).

The peaks $1682 \mathrm{~cm}^{-1}$ to $1670 \mathrm{~cm}^{-1}$ are representing $-\mathrm{C}=\mathrm{C}-$ stretching vibrations which indicates the presence of alkanes. A small peak at $1281 \mathrm{~cm}^{-1}$ indicates the presence of ester group. The frequency range of 3800$3200 \mathrm{~cm}^{-1}$ present in $\mathrm{O}-\mathrm{H}$ stretching vibration confirms the presence of alcohols/phenols.

The FTIR analysis of Lagerstoermia speciosa dye has absorption bands at $575 \mathrm{~cm}^{-1}, 1040$ $\mathrm{cm}^{-1}, 1169 \mathrm{~cm}^{-1}, 1466 \mathrm{~cm}^{-1}, 1654 \mathrm{~cm}^{-1}, 1736$ $\mathrm{cm}^{-1}, 2878 \mathrm{~cm}^{-1}, 2927 \mathrm{~cm}^{-1}, 3298 \mathrm{~cm}^{-1}$ and $3763 \mathrm{~cm}^{-1}$. The peak at frequency of 1040 $\mathrm{cm}^{-1}, 2927 \mathrm{~cm}^{-1}$ and $3298 \mathrm{~cm}^{-1}$ were strong while other peaks were medium to weak. The strong peaks at $1040 \mathrm{~cm}^{-1}$ represents the presence of aliphatic amines, $2927 \mathrm{~cm}^{-1}$ indicates the presence of alkanes and smooth peak at $3298 \mathrm{~cm}^{-1}$ strongly indicates the presence of alcohols/phenols.

\section{Phytochemical profiling}

The phytochemical analysis of Glycyrrhiza glabra and Lagerstoermia speciosa dye extract indicated the presence of various bioactive compounds as shown in Table 3 . The Glycyrrhiza dye extract indicates the presence of tannins, quinones, glycosides, phenol, saponins and terpenoids. Sharma et al., (2013) also reported the presence of tannins, terpenoids, glycosides and saponins in the methanolic root extract of Glycyrrhiza glabra.

The qualitative phytochemical analysis of Lagerstoermia speciosa dye extract confirms the presence of tannins, anthocyanins, flavanones, glycosides, phenol and saponins. Azad et al., (2019) also confirms the presence of glycosides, saponins and phenols in the ethanolic leaf extract of Lagertoermia speciosa.

\section{Dyeing of wool fabric with natural dyes and testing of its functional properties}

The filtered solutions of both the dyes were used for dyeing of wool fabric at $80^{\circ} \mathrm{C}$ for 60 minutes. The colours obtained on wool fabric using Glycyrrhiza glabra and Lagerstoermia speciosa dyes are shown in Figure 2a and b.

These dyed fabrics were tested for antibacterial activity against S.aureus and E.coli using AATCC-147 method. The UPF and colour strength of both the dyed samples were also tested. The results obtained are shown in Table 4.

It is evident from Table 4 that the Lagerstoermia speciosa dyed samples showed good antibacterial activity against E.coli $(2 \mathrm{~cm})$ but very less antibacterial activity against S.aureus $(0.2 \mathrm{~cm})$. In case of Glycyrrhiza glabra dyed samples, the inhibition zone (Fig. 3 ) was more against S.aureus $(2 \mathrm{~cm})$ but less against E.coli $(1 \mathrm{~cm})$. When compared to the antibacterial activity of dye solutions shown in Table 2, the zone of inhibition reduces in case of dyed fabric.

This may be due to the fact that the dye concentration was not sufficient enough for antibacterial activity on dyed fabric. 
Table.1 Physical properties of wool fabric

\begin{tabular}{|c|c|c|}
\hline \multicolumn{2}{|c|}{ Properties } & Wool \\
\hline \multicolumn{2}{|c|}{ Fabric Weight $\left(\mathbf{g} / \mathbf{c m}^{-1}\right)$} & 2.321 \\
\hline \multirow{2}{*}{ Tensile Strength $(\mathbf{K g F})$} & Warp & 34.15 \\
\cline { 2 - 3 } & Weft & 36.9 \\
\hline \multirow{2}{*}{ Elongation (\%) } & Warp & 38.5 \\
\hline & Weft & 38 \\
\hline
\end{tabular}

Table.2 Antibacterial activity of extracted natural dyes

\begin{tabular}{|c|c|c|}
\hline \multirow{2}{*}{ Natural Dye } & \multicolumn{2}{|c|}{ Zone of Inhibition $(\mathbf{m m})$} \\
\cline { 2 - 3 } & S. aureus & E.coli \\
\hline Glycyrrhiza glabra & 10 & 6 \\
\hline Lagerstoermia speciosa & 3 & 6 \\
\hline
\end{tabular}

Table.3 Phytochemical analysis of extracted dyes

\begin{tabular}{|c|c|c|}
\hline Phytochemicals & Glycyrrhiza glabra & Lagerstoermia speciosa \\
\hline Tannins & + & + \\
\hline Anthraquinones & - & - \\
\hline Anthocyanin and Flavanones & - & + \\
\hline Coumarins & - & - \\
\hline Quinones & + & - \\
\hline Glycosides & + & + \\
\hline Flavonoids & - & - \\
\hline Phenol & + & + \\
\hline Saponins & + & + \\
\hline Terpenoids & + & - \\
\hline
\end{tabular}

Key: + Present - Absent

Table.4 Functional properties of fabric dyed using glycyrrhiza \& lagerstoermia dyes

\begin{tabular}{|c|c|c|c|c|c|}
\hline \multirow[t]{2}{*}{ Name of the plant } & \multirow{2}{*}{$\begin{array}{c}\text { Colour } \\
\text { strength } \\
(\mathbf{k} / \mathbf{s})\end{array}$} & \multicolumn{2}{|c|}{$\begin{array}{c}\text { Zone of Inhibition } \\
(\mathbf{c m})\end{array}$} & \multirow[t]{2}{*}{ UPF } & \multirow[t]{2}{*}{ UV protective class } \\
\hline & & S.aureus & E.coli & & \\
\hline Blank wool & 0.844 & 0 & 0 & 60.6 & Excellent \\
\hline Lagerstoermia speciosa & 16.595 & 0.5 & 2 & 146 & Excellent \\
\hline Glycyrrhiza glabra & 15.523 & 2 & 1 & 107 & Excellent \\
\hline
\end{tabular}

Table.5 Colour fastness properties of dyed samples

\begin{tabular}{|c|c|c|c|c|c|c|c|}
\hline Name of the plant & \multicolumn{2}{|c|}{ Washing fastness } & \multicolumn{4}{|c|}{$\begin{array}{c}\text { Light } \\
\text { fastness }\end{array}$} & \multicolumn{3}{|c|}{ Crocking fastness } \\
\cline { 5 - 8 } & & & & Dry & \multicolumn{2}{|c|}{ Wet } \\
\cline { 5 - 8 } & CC & CS & & CC & CS & CC & CS \\
\hline Lagerstoermia speciosa & 3 & $4-5$ & 5 & 5 & $4-5$ & $4-5$ & $4-5$ \\
\hline Glycyrrhiza glabra & 4 & 4 & 5 & 5 & $4-5$ & 5 & 4 \\
\hline
\end{tabular}


Fig.1 FTIR spectra of Glycyrrhiza glabra and Lagerstoermia speciosa dye

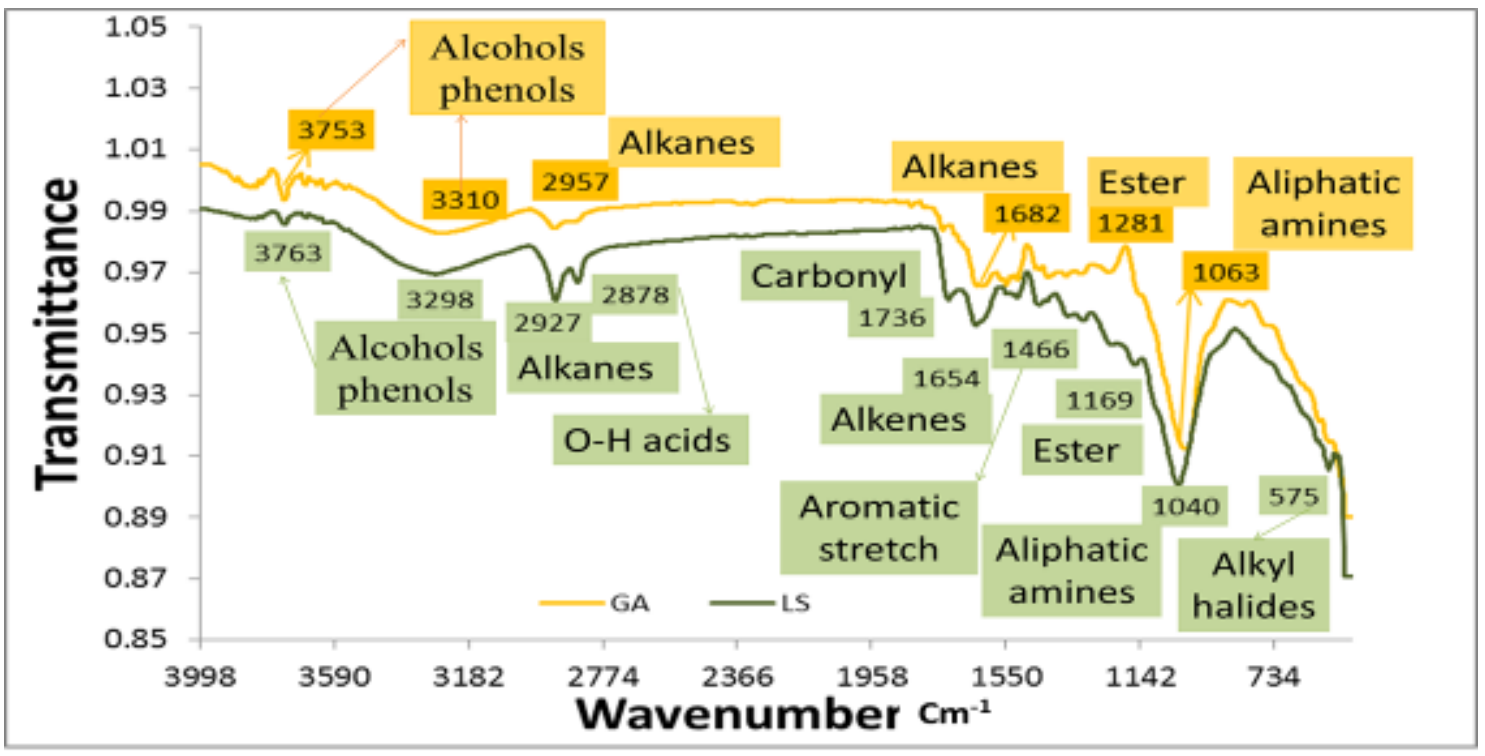

Fig.2 Dye powders and colours obtained on wool fabric

a) Glycyrrhiza glabra
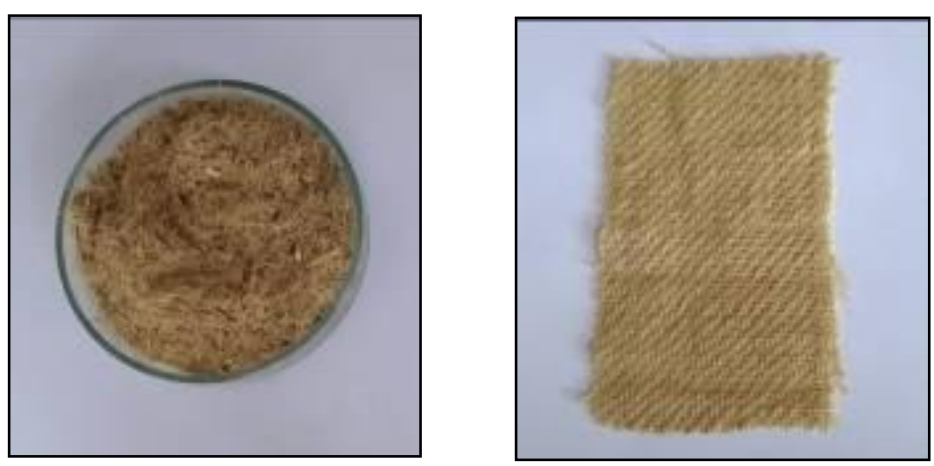

b) Lagerstoermia speciosa
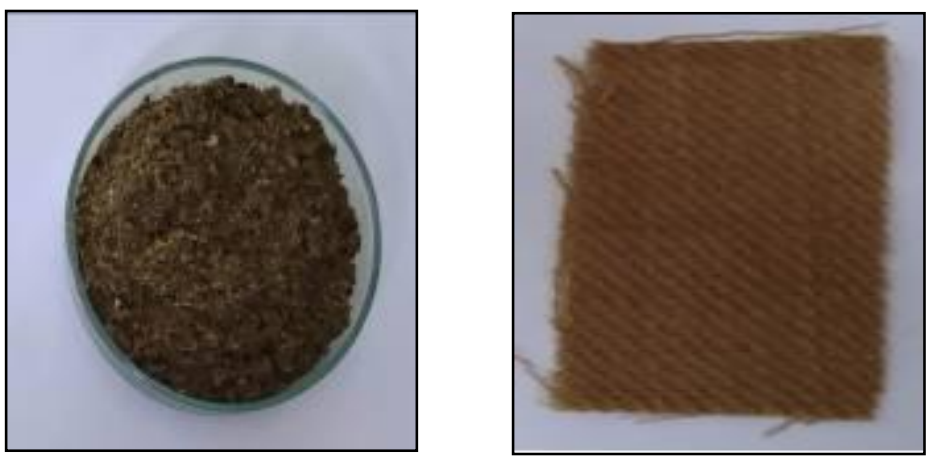
Fig.3 Zone of inhibition produced by dyed wool fabric

\section{Lagerstoermia speciosa}

S.aureus

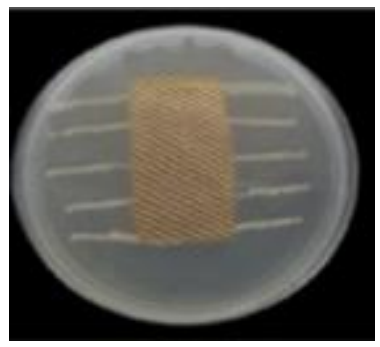

Glycyrrhiza glabra
E.coli
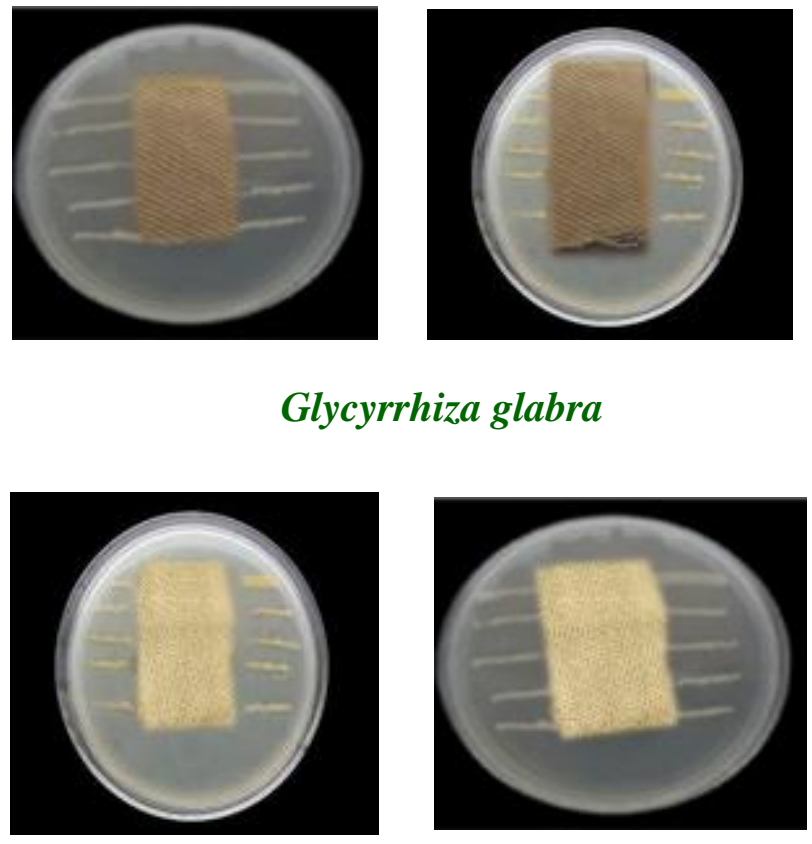

The amount of dye absorbed by the fabric may be less which ultimately reduces the antibacterial activity of dyed fabric as compared to solution. The results were also in line with the statement of Singh et al., 2004 that the reduction in antimicrobial activity was observed when extract of dye was applied on wool fabric. This is due to the reason that concentration of dye was not sufficient enough for fabric to impart high antibacterial activity. It is also inferred from the data that the Lagerstoermia speciosa dyed wool exhibit higher $\mathrm{k} / \mathrm{s}$ value i.e. 16.595 as compared to Glycyrrhiza glabra (15.523).

In case of ultraviolet protection factor, it was observed from the Table 4 that Lagerstoermia speciosa dyed samples exhibits higher ultraviolet protection (146) as compared to Glycyrrhiza glabra (107) dyed samples. Both the dyed samples were found to be in excellent category of UPF according to AS/NZS-4399 standards. Herbazest, 2015 also mentioned that licochalcone an active compound in licorice roots provides protection against UV rays.

Kolakul and Sripanidkulchai, 2018 also reported the protective effects of Lagerstoermia speciosa extract against UV-A radiation and mentioned it as a potential therapeutic agent to prevent skin photo aging.

\section{Assessment of colour fastness properties}

The Lagerstoermia speciosa dyed samples as indicated in the Table 5 showed noticeable change in colour in washing fastness and slight to negligible colour staining.

The washing fastness of Glycyrrhiza glabra dyed samples showed slight change in colour and slight staining on wool fabric. In case of fastness to light, the Lagerstoermia speciosa 
and Glycyrrhiza glabra dyed samples showed good fastness to light.

In case of Lagerstoermia speciosa dyed samples no change in colour (5) was observed during dry crocking but exhibited slight to negligible colour staining on cotton fabric. The dyed samples also showed negligible to slight colour change (4-5) and colour staining (4-5) on cotton fabric during wet crocking.

Table 5 also shows that there is no change in colour (5) during dry crocking of Glycyrrhiza glabra dyed fabric but slight to negligible staining was observed on cotton fabric. The wet crocking of Glycyrrhiza glabra dyed fabric show no change in colour (5) and slight staining was observed on cotton fabric.

This study envisages the development of new potential natural dye sources and its utilization for imparting functional as well as aesthetic properties through sustainable dyeing of wool fabric. The plants under study utilize waste leaves of Lagerstoermia speciosa and the roots of Glycyrrhiza glabra which can be obtained through sustainable crop production. The present work showed that Lagerstoermia speciosa and Glycyrrhiza glabra gives acceptable colours on wool fabric. Both the dyes give excellent antibacterial activity in solution and dyed fabric also showed good antibacterial activity against human pathogens. Both the dyed fabrics provide excellent protection against harmful UV rays. The people who live at higher altitudes are more exposed to UV rays so these dyed wool fabrics will be a potential alternative in developing protective clothing to provide sun protection and also protect wearer's skin from harmful bacterial infections. It is a sustainable technique which may foresee the viability of natural dye production on commercial scale. The study also serves as a potential alternative for upliftment of rural societies in developing countries like India as well as provides alternate employment opportunities to meet their basic needs.

\section{References}

Azad, K.A., Azizi, S.W., Ismail, A., Abbas, S., Uddin, J. and Labu, Z. 2019. Phytochemical and toxicity evaluation of traditional herb: Lagerstoermia speciosa (Banaba) by MCF-7 cell line and brine shrimp lethality bioassay. 22(1): 45-49.

Bechtold, T., Turcanu, A., Ganglberger, E. and Geissler, S. 2003. Natural dyes in modern textile dye houses-how to combine experience of two centuries to meet the demands of the future? Journal of Cleaner Production. 11:499-509.

Calis, A., Celik, G.Y. and Katircioglu, H. 2009. Antimicrobial Effect of Natural Dyes on Some Pathogenic Bacteria. African Journal of Biotechnology. 8: 291-293.

Diab, Y., Atalla, K. and Elbanna, K.2012. Antimicrobial screening of some Egyptian plantsand active flavones from Lagerstoermia indica leaves. Drug Discoveries and Therapeutics. 6(4): 212-217.

Herbazest 2015 https://www.herbazest.com/news/licori ce-root-may-shield-skin-from-uvdamage.

Kolakul, P. and Sripanidkulchai, B. 2018. Protective effects of Lagerstoermia speciosa extract against UV-A damage on skin cells. Industrial Crops and Products. 124- 9-19.

Snafi, A. 2018. Glycyrrhiza glabra: A phytochemical and pharmacological review. Journal of Pharmacy. 8(6): 117.

Sharma, V., Agrawal, R.C. and Pandey, S. 2013. Phytochemical screening and determination of antibacterial and anti- 
oxidant potential of Glycyrrhiza glabra root extracts. Journal of Environment Research and Development. 7(4A): 1552-1558.

Singh, R., Jain, A., Panwar, S., Gupta, D. and Khare, K.S. 2005. Antibacterial activity of some natural dyes. Dyes and Pigments. 66:99-102.

Snafi, A. 2018. Glycyrrhiza glabra: A phytochemical and pharmacological review. Journal of Pharmacy. 8(6): 117.

Theivandran, G., Ibrahim, S. and Murugan, M. 2015. Fourier Transfer Infrared (FT-Ir) Spectroscopic Analysis of Spirulina fusiformis. Journal of Medicinal Plant Studies. 3(4): 30-32.

\section{How to cite this article:}

Aaditaa Singh and Shahnaz Jahan. 2019. Extraction of Natural Dyes from Glycyrrhiza glabra and Lagerstroemia speciosa for Wool Dyeing and Testing of its Functional Properties. Int.J.Curr.Microbiol.App.Sci. 8(12): 2119-2129. doi: https://doi.org/10.20546/ijcmas.2019.812.251 